\title{
Ekspor dan Impor Barang Serta Perpajakan Bagi Pelaku Usaha UMKM
}

Sahdan Maulana*1, Ayu Fitrianingrum² ${ }^{2}$ Abieza Satya Damara3 ${ }^{3}$ Enno Astri Quinta ${ }^{4}$, Evie Puspita

Sari $^{5}$, Kartiko Hariputra ${ }^{6}$, M. Ilham Mu'arief ${ }^{7}$, Utari Ayuningrum Zuti ${ }^{8}$, Taufik Raharjo ${ }^{9}$

1,2,3,4,5,6,7,89 Politeknik Keuangan Negara STAN; Jl Bintaro Utama 3A No.V, Bintaro, Ciputat Timur, Tangerang Selatan, Banten, 021-7361654

3Program Studi D3 Kebendaharaan Negara, Jurusan Manajemen Keuangan,

Politeknik Keuangan Negara STAN

*e-mail: sahdanmaulana50@gmail.com

\begin{abstract}
The purpose of this community service activity is to provide a basic understanding and foster awareness of MSME entrepreneurs, especially for the Banana Chips Karya Mandiri Store, Bandar Lampung, in fulfilling tax obligations and providing information related to the export-import activities of goods that can be carried out in connection with the business being run. These community service activities are divided into two main sub-categories namely tax knowledge and goods export-import knowledge. After the implementation of community service activities, it can be concluded that business owners and employees of the Banana Chips Karya Mandiri Store can understand the latest MSME taxation regulations, especially tax obligations that must be implemented. Besides, business owners and employees of the Banana Panan Karya Mandiri Store can understand the export-import provisions for personal goods or goods for business entities as well as the provisions regarding Hajj and Umrah luggage.
\end{abstract}

Keywords: Tax, Export, Import, SME, Services

\section{Abstrak}

Tujuan kegiatan pengabdian masyarakat ini adalah memberikan pemahaman mendasar serta menumbuhkan kesadaran pelaku usaha UMKM khususnya bagi Toko Keripik Pisang Karya Mandiri, Bandar Lampung, dalam memenuhi kewajiban perpajakan dan memberikan informasi terkait kegiatan ekspor-impor barang yang bisa dilakukan sehubungan dengan usaha yang dijalankan. Kegiatan pengabdian masyarakat ini terbagi dalam dua sub utama yaitu pengetahuan perpajakan dan pengetahuan ekspor-impor barang. Setelah pelaksanaan kegiatan pengabdian kepada masyarakat ini dapat disimpulkan bahwa pemilik usaha dan karyawan Toko Keripik Pisang Karya Mandiri dapat memahami peraturan perpajakan UMKM terbaru, khususnya kewajiban-kewajiban perpajakan yang harus dilaksanakan. Selain itu pemilik usaha dan karyawan Toko Keripik Pisang Karya Mandiri dapat memahami ketentuan ekspor-impor barang pribadi atau barang untuk badan usaha serta ketentuan mengenai barang bawaan haji dan umrah.

Kata kunci: Pajak, Ekspor, Impor, UMKM, Pengabdian

\section{PENDAHULUAN}

Dalam beberapa tahun terakhir sektor Usaha Mikro Kecil Menengah (UMKM) telah berhasil menjelma menjadi sumber penggerak ekonomi baru di Indonesia. Tambunan [7] mendefinisikan UMKM sebagai sebuah unit usaha yang mandiri dan berdiri sendiri, dimana dilakukan oleh orang perorangan atau Badan Usaha. Kontribusi UMKM terhadap Produk Domestik Bruto (PDB) tercatat mencapai 61,41 persen. Dengan dominasi tersebut, UMKM setidaknya menyerap hampir 97 persen total tenaga kerja nasional dan memiliki proporsi 99 persen dari total pelaku usaha di Indonesia.

Maka tidak berlebihan apabila kita menyebut bahwa ekonomi di Indonesia tumbuh pesat lewat sektor UMKM. Peran UMKM terhadap perekonomian dan penyerapan tenaga kerja memang tidak lagi diragukan. Namun, dalam sektor perpajakan, UMKM belum mencerminkan kontribusi yang dominan sebagaimana pengaruhnya terhadap perekonomian dan penyerapan tenaga kerja. Pada tahun 2014, sumbangsih penerimaan pajak dari PPh Final UMKM hanya sekitar Rp2 triliun. Dengan asumsi UMKM berkontribusi Rp.3.000 trilliun terhadap PDB, nilai itu masih relatif jauh dibawah potensi perpajakan sebesar Rp30 triliun (1 persen dari kontrobusi terhadap PDB). 
Menurut Mardiasmo [2], pajak merupakan iuran rakyat kepada kas negara berdasarkan undang-undang (yang dipaksakan) dengan tiada mendapat jasa timbal balik (kontraprestasi) yang langsung ditunjukkan dan yang digunakan untuk membayar pengeluaran umum. Waluyo [11] menyamoaikan bahwa Pajak merupakan prestasi yang dipaksakan sepihak oleh dan terutang kepada pengusaha (menurut norma-norma yang ditetapkannya secara umum) tanpa adanya kontraprestasi dan semata-mata digunakan untuk menutup pengeluaran-pengeluaran. Pengertian Pajak menurut Undang-Undang Nomer 28 Tahun 2007 tentang Ketentuan Umum dan Tata Cara Perpajakan [10], pajak adalah kontribusi wajib kepada negara yang terutang oleh orang pribadi atau badan yang bersifat memaksa berdasarkan Undang-Undang, dengan tidak mendapatkan imbalan secara langsung dan digunakan untuk keperluan negara bagi sebesarbesarnya kemakmuran rakyat. Resmi [5] berpendapat bahwa pajak berfungsi sebagai sumber keuangan Negara dan pengaturan. Sebagai fungsi pengeturan, pajak merupakan salah satu penerimaan pemerintah untuk membiayai pengeluaran baik rutin maupun pembangunan. Sebagai pengatur, pajak sebagai alat untuk mengatur atau melaksanakan kebijakan pemerintah dalam bidang social dan ekonomi, serta mencapai tujuan-tujuan tertentu di luar bidang keuangan.

Sehingga bisa disimpulkan bahwa pajak adalah suatu iuran yang harus dibayar setiap warga negara yang bersifat memaksa karena telah diatur sedemikian rupa dalam Undang-Undang yang dipungut oleh negara baik pemerintah pusat maupun pemerintah daerah, dan hasil pembayaran pajak yang Wajib Pajak lakukan tidak langsung terlihat hasilnya. Untuk itu, menggali potensi penerimaan pajak UMKM merupakan salah satu fokus kerja Kementerian Keuangan (Kemenkeu). Guna mencapai tujuan itu, Kemenkeu terus berupaya meningkatkan tingkat partisipasi pajak UMKM dengan menciptakan ekosistem perpajakan yang ramah. Pemetaan perpajakan yang mudah bagi UMKM pun terus disusun.

Salah satu caranya adalah dengan penerapan tarif yang mudah dan ringan bagi UMKM. Berdasarkan Peraturan Pemerintah No. 23/2018 tentang Pajak Final UMKM, pemerintah telah memberikan skema khusus berupa pajak penghasilan final 0,5 persen dari total penghasilan yang diperoleh bagi UMKM (penghasilan bruto) dengan omzet hingga Rp4,8 milliar sebagai upaya merangkul partisipasi perpajakan UMKM agar menjadi lebih luas. Lebih dari itu, langkah dalam menciptakan perpajakan yang ramah juga disambut baik oleh Direktorat Jenderal Bea dan Cukai dengan memberikan fasilitas Kemudahan Impor Tujuan Ekspor untuk Industri Kecil Menengah (KITE IKM) guna mendorong UMKM menembus pasar global. Menurut Mankiw [1], ekspor adalah berbagai macam barang dan jasa yang diproduksi di dalam negeri lalu di jual di luar negeri. Berdasarkan Undang-Undang Nomor 17 Tahun 2006 tentang Perubahan Undang-Undang No. 10 Tahun 1995 tentang Kepabeanan [9], ekspor adalah kegitan mengeluarkan barang keluar daerah pabean sesuai dengan UU Kepabeanan. Menurut Susilo [6] impor bisa diartikan sebagai kegiatan memasukkan barang dari suatu negara (luar negeri) ke dalam wilayah pabean negara lain (dalam negeri). Pengertian ini memiliki arti bahwa kegiatan impor berarti melibatkan dua negara. Dalam hal ini bisa diwakili oleh kepentingan dua perusahaaan antar dua negara tersebut, di mana satu pihak bertindak sebagai penjual (eksportir) dan satunya sebagai pembeli (importir). Sedangkan menurut Tanjung [8] transaksi impor adalah perdagangan dengan cara memasukkan barang dari luar negeri ke dalam daerah pabean Indonesia dengan mematuhi ketentuan peraturan perudang-undangan yang berlaku. Menurut peraturan perundang undangan [5] Impor adalah kegiatan memasukkan barang ke dalam daerah pabean. Sedangkan yang dimaksud dengan daerah pabean adalah wilayah Republik Indonesia yang meliputi wilayah darat, perairan dan ruang udara diatasnya, serta tempat-tempat tertentu di Zona Ekonomi Eksklusif dan landas kontinen yang di dalamnya berlaku Undang-Undang ini. Melalui fasilitas ekspor-impor ini, saat mengimpor barang modal dan bahan baku guna membuat produk untuk diekspor, industri kecil menengah diberikan pembebasan bea masuk, Pajak Pertambahan Nilai (PPN), dan Pajak Penjualan atas Bawang Mewah (PPnBM). Hal ini bertujuan untuk menciptakan iklim produksi impor-ekspor yang ringan bagi UMKM. Langkah-langkah tesebut merupakan wujud nyata untuk menciptakan pajak yang ramah bagi mitra UMKM. Dengan berbasis rasa saling percaya dan semangat kontribusi itulah, pajak menjadi instrumen dalam mendorong perekonomian nasional. 
Dan dalam sektor UMKM, pajak mencoba hadir secara membumi bagi UMKM. Sehingga diharapkan mampu meningkatkan UMKM untuk tidak hanya ada dominan dalam mengembangkan perekonomian bangsa namun juga bisa memberikan sumbangsihnya untuk turut bergotong-royong membangun negara yang adil, makmur, dan berdaulat, melalui pajak. (kemenkeu.go.id 20/03/2018)

Toko Keripik Pisang Karya Mandiri adalah UMKM yang bergerak dibidang industri rumahan, dimana kegiatan utamanya memproduksi keripik pisang khas Bandar Lampung. Tak hanya itu, untuk memenuhi kebutuhan pasar, saat ini UMKM Keripik Pisang Karya Mandiri juga telah memproduksi beberapa produk makanan lainnya seperti kopi bubuk olahan, pisang sale, jagung marning dan keripik singkong. Semua hasil produksi tersebut dijual sendiri melalui Toko yang dimiliki dijalan pagar alam (gg PU) Bandar Lampung. UMKM Keripik Pisang Karya Mandiri juga menerima titipan barang dagangan dari produsen makanan lain misalnya kerupuk kemplang, emping jagung dan kelanting. Sehingga UMKM Keripik Pisang Karya Mandiri dapat dikategorikan sebagai usaha yang cukup lengkap dalam memenuhi kebutuhan pelanggan khususnya wisatawan yang sedang mencari oleh-oleh khas Bandar Lampung. Hingga saat ini, Kesadaran pemenuhan kewajiban perpajakan dan pengetahuan akan pentingnya pajak bagi negara yang bersumber dari UMKM serta pengetahuan Pemilik UMKM Keripik Pisang Karya Mandiri mengenai ketentuan impor dan/atau ekspor barang pribadi dan barang untuk badan usaha masih tergolong minim.

Mengingat kontribusi usaha dari sektor UMKM saat ini sangat besar bagi perekonomian negara khususnya dalam bidang perpajakan serta potensi pasar yang luar biasa diluar negeri dengan segala fasilitas yang telah disediakan oleh pemerintah untuk mengakomodasi ekspor produk-produk yang telah dihasilkan oleh sentra usaha UMKM ini, maka perlu adanya sosialisasi peraturan-peraturan terbaru mengenai sub tema tersebut sebagaimana yang telah kami pelajari dikampus. Mengingat besarnya potensi yang dimiliki oleh usaha UMKM dalam menggerakkan perekonomian indonesia, saat ini pemerintah telah membuat peraturan baru dengan menurunkan tarif PPh bagi usaha UMKM dengan harapan agar usaha mikro dapat tumbuh loncat menjadi usaha kecil, usaha kecil juga bisa tumbuh menjadi usaha menengah, usaha menengah menjadi usaha yang besar. Selain itu, saat ini pemerintah telah menyediakan berbagai macam kemudahan bagi pelaku usaha UMKM untuk mengekspor produk-produknya keluar negeri.. Namun nyatanya UMKM Keripik Pisang Karya Mandiri belum memahami dengan baik peraturanperaturan tersebut. Dengan demikian maka perlu adanya kegiatan pengabdian masyarakat berupa sosialisasi perpajakan UMKM dan Sosialisasi Ketentuan Impor dan/atau Ekspor Barang Pribadi atau Barang untuk Badan Usaha.

Materi Sosialisasi yang disampaikan berupa peraturan perpajakan UMKM terbaru PP 23/2018 dan kewajiban-kewajiban perpajakan yang harus dipenuhi sebagai usaha UMKM. Serta Ketentuan Impor dan/atau Ekspor Barang Pribadi dan Barang untuk Badan Usaha yang didalamnya sudah mencakup materi mengenai barang bawaan haji dan umrah. Sosialisasi tersebut disampaikan melalui media laptop dan leaflet. Materi sosialisasi yang disampaikan dibuat sedemikian rupa untuk memudahkan peserta memahami apa yang telah disampaikan oleh mahasiswa, baik berupa gambar, animasi dan video. Dalam penyampaian materi juga dipersilahkan untuk bertanya jika terdapat hal-hal yang belum dimengerti dan juga terdapat simulasi untuk menghitung besarnya pajak terutang.

Tujuan kegiatan pengabdian masyarakat ini antara lain :

1. Memberikan pemahaman peraturan perpajakan UMKM dalam upaya meningkatkan kepatuhan perpajakan;

2. Memberikan pemahaman tentang Ketentuan Impor dan/atau Ekspor Barang Pribadi atau Barang untuk Badan Usaha serta barang bawaan haji dan umrah. 


\section{METODE}

Metode pelaksanaan kegiatan pengabdian kepada masyarakat ini dilakukan dengan tiga tahapan pelaksanaan, yaitu:

1. Identifikasi masalah dan rencana aksi

Tahap ini mencoba mencari kendala yang terjadi dalam pemenuhan kewajiban perpajakan pengelolaan dan pemahaman terkait Impor dan/atau Ekspor Barang Pribadi atau Barang untuk Badan Usaha, kemudian membuat rencana aksi untuk memberikan solusi dari permasalahan yang ada. Hal ini dilakukan agar kegiatan pengabdian ini tepat manfaat.

2. Persiapan

Setelah mendapatkan rencana aksi maka dilakukan persiapan kegiatan pengabdian masyarakat.

3. Pelaksanaan kegiatan

Kegiatan pengabdian ini dilaksanakan untuk menindakanjuti rencana kegiatan dan mencoba menyelesaikan masalah yang telah diidentifikasi.

\section{HASIL DAN PEMBAHASAN}

Hasil pengabdian kepada masyarakat ini mendapatkan beberapa hasil yang diharapkan mempunyai efek positif bagi mitra.

\subsection{Identifikasi Masalah dan rencana solusi}

Identifikasi masalah dilakukan melalui wawancara dengan pemilik UMKM Keripik Pisang Karya Mandiri. Salah satu kendalanya adalah minimnya kesadaran untuk taat dalam menjalankan kewajiban perpajakan serta rendahnya pemahaman terkait peraturan-peraturan terbaru baik yang terkait perpajakan UMKM maupun Impor dan/atau Ekspor Barang Pribadi atau Barang untuk Badan Usaha. Mengingat pemenuhan perpajakan merupakan kewajiban sebagai warga negara sebagai mana telah diatur dalam undang-undang serta pentingnya pengetahuan peraturan Impor dan/atau Ekspor Barang Pribadi atau Barang untuk Badan Usaha untuk ekspansu usaha, maka kami mengajukan kegiatan pengabdian berupa sosialisasi pemenuhan kewajiban perpajakan UMKM dan Sosialisasi Ketentuan Impor dan/atau Ekspor Barang Pribadi atau Barang untuk Badan Usaha. Kegiatan sosialisasi perpajakan merupakan adopsi dari kegiatan pengabdian kepada masyarakat oleh Raharjo [4] yang disusun dalam program Business Development Service (BDS) dibawah Direktorat Jendral Pajak. Raflis [3] menjelaskan bahwa pengenalan Akuntansi dan Perpajakan bagi masyarakat menjadi hal yang di butuhkan, karena msyarakat umum masih manila bahwa proses akuntansi dan perpajakan merupakan hal rumit. Maka, melalui kegiatan pengabdian masyarakat ini, kami mencoba memberikan sosialisasi perpajakan dengan metode yang mudah dipahami oleh semua kalangan.

\subsection{Persiapan}

Kegiatan yang dilakukan dalam persiapan ini adalah koordinasi internal tim pengabdi untuk mencari jadwal yang sesuai dalam melaksanakan kegiatan serta menyiapkan materi hingga bahan yang tepat untuk disampaikan dalam kegiatan sosialisasi tersebut. Dalam pelaksanaan kegiatan sosialisasi ini dilakukan pembagian tugas untuk masing-masing bagian, meliputi:

1. Sosialisasi pemenuhan kewajiban perpajakan UMKM, menjelaskan peraturan tarif perpajakan UMKM terbaru PP 23/2018, kewajiban-kewajiban perpajakan yang harus dipenuhi sebagai usaha dari sektor UMKM

2. Sharing Knowledge, Mendapatkan pemahaman tentang pemenuhan kewajiban perpajakan yang telah dilakukan serta memberikan saran dan solusi terkait kendala dalam pemenuhan kewajiban perpajakan. 
3. Sosialisasi Ketentuan Impor dan/atau Ekspor Barang Pribadi atau Barang untuk Badan Usaha, menjelaskan peraturan nomor 203/PMK.04/2017 yang mengatur tentang ketentuan Impor dan/atau Ekspor Barang Pribadi atau Barang untuk Badan Usaha, serta ketentuan mengenai barang bawaan haji dan umrah.

\subsection{Pelaksanaan Sosialisasi}

Sosialsasi pemenuhan kewajiban perpajakan UMKM diselenggarakan pada hari rabu Tanggal 24 Juli 2019 di Toko usaha Keripik Pisang Karya Mandiri sejak pukul 09.00 WIB s.d. 11.00 WIB. Kegiatan tersebut diikuti oleh seluruh angota pengabdian, seorang pemilik UMKM, dan enam orang karyawan UMKM Keripik Pisang Karya Mandiri.

Materi yang disampaikan dalam sosialisasi perpajakan ini adalah mengenai kewajibankewajiban perpajakan yang harus dilaksanakan oleh usaha UMKM meliputi pendaftaran sebagai wajib pajak, penghitungan besarnya pajak yang terutang (sebagaimana saat ini telah diatur dalam PP 23/2018), penyetoran pajak terutang ke kas negara dan pelaporan SPT, memberikan gambaran atas peran pajak yang dihasilkan dari usaha UMKM dalam realisasi penerimaan negara sektor perpajakan tahun ketahun, serta pentingnya pajak bagi pembangunan negara.

Sharing Knowledge Session, sebagai lanjutan atas materi yang disampaikan pada tanggal 24 juli 2019 dilakukan ditempat yang sama tanggal 25 juli 2019, kali ini lebih keberbagi pengalaman yang dimiliki oleh usaha UMKM Keripik Pisang Karya Madiri dalam memenuhi kewajiban perpajakannya dan segala kendala yang pernah dihadapi. Selain itu pada sesi kali ini juga diberikan simulasi cara menghitung besarnya pajak terutang atas penghasilan yang diterima dari kegiatan usaha UMKM yang dijalankan sesuai dengan peraturan terbaru PP 23/2018.

Kegiatan terakhir adalah Sosialisasi Ketentuan Impor dan/atau Ekspor Barang Pribadi atau Barang untuk Badan Usaha dilaksanakan pada tanggal 26 juli 2019, materi yang disampaikan adalah Peraturan Nomor 203/PMK.04/2017 yang mengatur tentang ketentuan Impor dan/atau Ekspor Barang Pribadi atau Barang untuk Badan Usaha tak lupa juga disampaikan materi terkait barang bawaan haji dan umrah sebagaimana diminta oleh pemilik usaha UMKM Keripik Pisang Karya mandiri saat wawancara.

Pada kenyataannya, setiap kegiatan pengabdian kepada masyarakat pasti mengalamai kendala, pun seperti dalam kegiatan ini. Kendala yang jelas kami rasakan dalam kegiatan sosialisasi ini adalah singkatnya waktu yang ada untuk memberikan informasi ataupun pengetahuan baru terhadap semua peraturan terkait perpajakan dan impor/ekspor barang. Masalah lain yaitu, belum tersediannya media yang memadai dalam menyampaikan materi sosialisasi sehingga terbatas hanya melalui layar laptop yang kecil dan hanya sebagian materi saja yang telah dilengkapi dengan leaflet. Ditambah dengan tidak adanya tempat yang cukup luas yang bisa menampung semua peserta pengabdian dan karyawan UMKM sehingga sedikit mengganggu jalannya kegiatan sosialisasi. 


\section{Tabel dan Gambar}

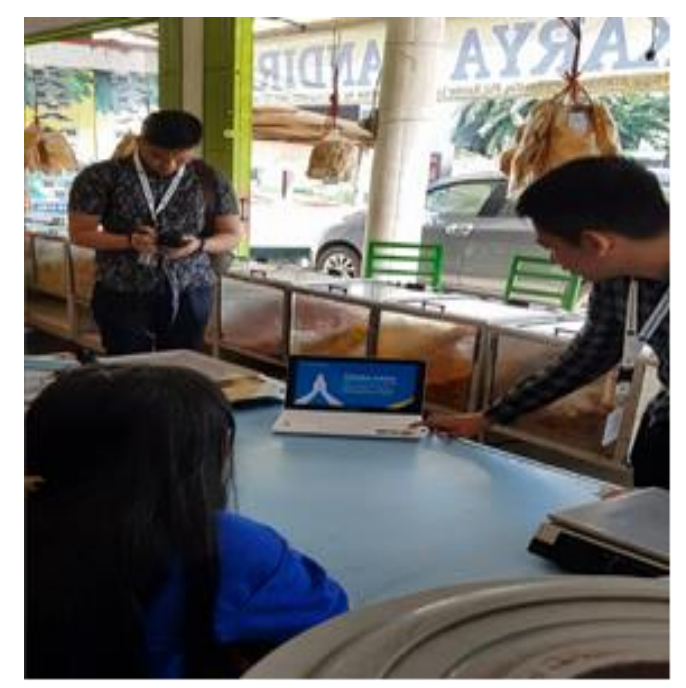

Gambar 1. Sosialisasi pemenuhan kewajiban perpajakan UMKM

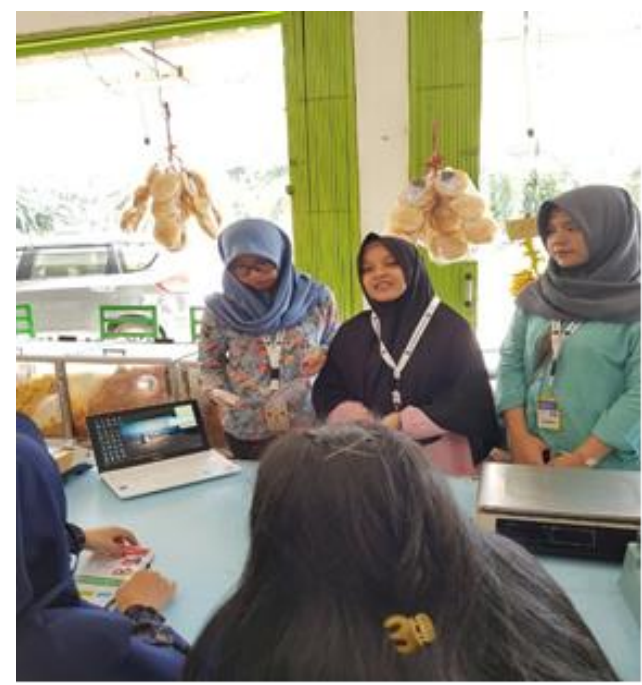

Gambar 2. Sharing Session

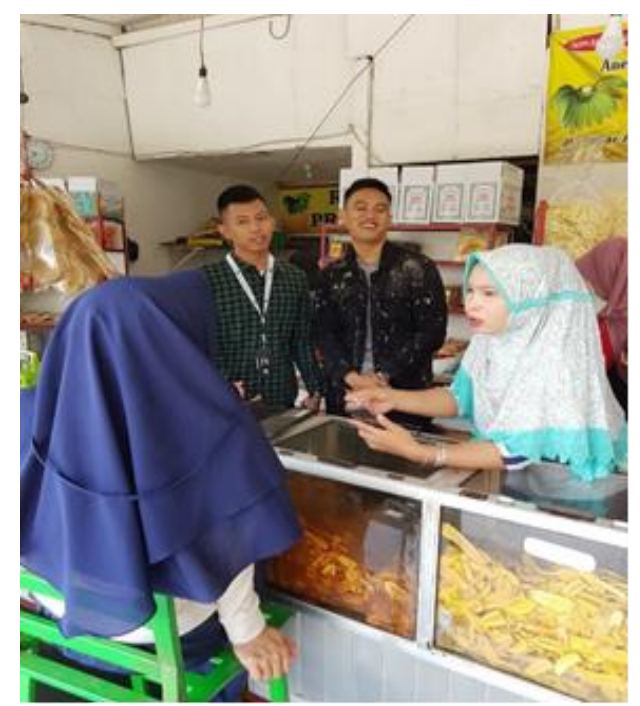

Gambar 3. Sosialisasi Ketentuan Impor dan/atau Ekspor Barang Pribadi atau Barang untuk Badan Usaha 


\section{KESIMPULAN}

Setelah pelaksanaan kegiatan pengabdian kepada masyarakat ini dapat disimpulkan bahwa 1) Pemilik usaha UMKM Keripik Pisang Karya Mandiri dapat memahami peraturan perpajakan UMKM terbaru serta kewajiban-kewajiban perpajakan yang harus dilaksanakan. Penyampaian pemahaman tentang perpajakan dilakukan melalui simulasi penghitungan $\mathrm{PPh}$ terutang yang didampingi oleh peserta pengabdian, hingga akhirnya pemilik usaha UMKM Keripik Pisang Karya Mandiri telah mampu menghitung sendiri PPh terutang atas kegiatan usaha yang dijalankan dengan benar; 2) Pemilik usaha dan karyawan UMKM Keripik Pisang Karya Mandiri dapat memahami Ketentuan Impor dan/atau Ekspor Barang Pribadi atau Barang untuk Badan Usaha serta ketentuan mengenai barang bawaan haji dan umrah.

\section{UCAPAN TERIMA KASIH}

Ucapakan terimakasih kami sampaikan kepada pemilik usaha Toko Keripik Pisang Karya Mandiri yang telah bersedia berkerjasama dengan Politeknik Keuangan Negara STAN (PKN STAN) dalam agenda pengabdian kepada masyarakat. Besar harapan kami, pelaksanaan kegiatan pengabdian ini dapat tetap terlaksana secara berkelanjutan dan membawa manfaat bagi usaha UMKM, khususnya pemilik usaha UMKM Keripik Pisang Karya Mandiri.

\section{DAFTAR PUSTAKA}

Raflis, R., Wijaya, R. S., \& Rahmi, Y. Y, 2019. Pelatihan Penerapan Akuntansi Dan Pajak Pada Badan Usaha Milik Nagari Barokah Lamo Kabupaten Sijunjung. Dinamisia: Jurnal Pengabdian Kepada Masyarakat, 3.

Raharjo, T., \& Khusnaini, K, 2018. Asistensi Pembuatan Laporan Keuangan Berbasis Android bagi Usaha Mikro, Kecil, dan Menengah. Wikrama Parahita: Jurnal Pengabdian Masyarakat, 2(2), 75-78.

Mankiw, N,Gregory, 2006. Makro Ekonomi, Terjemahan: Fitria Liza, Imam Nurmawan, Jakarta: Penerbit Erlangga.

Mardiasmo, 2016. Perpajakan Edisi Revisi Tahun 2016. Yogyakarta:Penerbit Andi.

Resmi,Siti. 2013. Perpajakan Teori dan Kasus. Salemba Empat. Jakarta.

Susilo, Andi, 2008.Buku Pintar Ekspor-Impor, Trans Media Pustaka.

Undang-Undang Nomor 17 Tahun 2006 tentang Perubahan Undang-Undang No. 10 Tahun 1995 tentang Kepabeanan.

Undang-Undang Nomor 28 Tahun 2007 tentang Ketentuan Umum dan Tata Cara Perpajakan.

Waluyo, 2011, Perpajakan Indonesia. Jakarta: Salemba Empat.

Tambunan, Tulus, 2012. "Usaha Mikro Kecil dan Menengah di Indonesia : isu-isu penting", Jakarta : LP3ES.

Tanjung, Abdul Hafiz, 2011. Akuntansi, Transparansi, dan Akuntabilitas Keuangan Publik (Sebuah Tantangan). 